\title{
Representasi Etnis Muslim Rohingya di Media Massa Islam
}

\author{
Dendy H Nanda \\ Institut Agama Islam Negeri (IAIN) Kerinci \\ dendynanda90@gmail.com
}

\begin{abstract}
Seeing the news about ethnic Rohingya some time lately we are often presented with a picture or reporting by our media, especially media that breathe Islam. Various forms of reporting were presented by the media. With different packaging between one media with another media. Of course it will be different between nationalist media media and religious ideologies. Starting from the perspective of the news, discussion in the text, or photos or images in the media. It is interesting if we look at how the media with the ideology of Islam in packaging the preaching. Often we see Islamic media in Indonesia displaying news about the ethnic Rohingya with great fanfare. Sometimes the writing tends to be provocative and looks like very dramatic. Starting from the headline, the content of the news to the photos displayed. As the headline in the online media Arrahmah.com when packing news with the title "Satanic Bald Buddha Myanmar Must Be Given Lessons Worthy" (Arrahmah.com, accesses 15 June 2013), this is certainly very provocative and as a media that carries religious symbols of course this will be difficult to accept with common sense. Another example "Rohingya Muslims suffer discrimination and persecution that is almost unceasing" (Arrahmah.com, access 15 June 2013). From the two examples of coverage above we can see how there are two different dichotomies displayed by Arrahman.com media. On one hand the Myanmar Buddhists are presented with very contempt with words that tend to be very insulting with the word "bald," while on the other hand the Rohingya Muslims are shown with very alarming conditions by using the word "endless persecution". Of course the news is very very provocative and contains elements of propaganda. Yet if we study in journalistic principles, every journalist must be professional and neutral. Where there must be a balance of facts in a story, but not with what happened in the media Arrahmah.com. This alignment is what the author considers relevant to what is said by the critical paradigm that there is no media that can be neutral, there is always an interest behind its preaching.
\end{abstract}

\section{Keywords: Rohinnya Muslim Ethnic, Islamic Mass Media}

\begin{abstract}
Abstrak. Melihat pemberitaan tentang etnis rohingya beberapa waktu belakangan ini seringkali kita disuguhkan dengan gambaran atau pemberitaan oleh media kita terutama media yang bernafaskan Islam. Berbagai bentuk pemberitaan di tampilakan oleh media tersebut. Dengan kemasan yang berbeda-beda antara satu media dengan media yang lain. Tentu akan berbeda antara media yag beraliran nasionalis dana media yang berideologikan agama. Mulai dari sudut pandang berita, pembahasaan di teks, maupun foto atau gambar yang ada di media tersebut. Menarik bila kita cermati
\end{abstract}


bagaimana media yang berideologikan Islam dalam mengemas pemberitaanya. Seringkali kita melihat media Islam di Indonesia menampilkan berita tentang etnis rohingya dengan sangat mengebu-gebu. Terkadang penulisannya cendrung provokatif dan kelihatan seperti sangat mendramatisir. Mulai dari judul berita, konten dari berita tersebut hingga foto-foto yang ditampilakan. Seperti yang menjadi kepala berita di media online Arrahmah.com ketika mengemas berit dengan judul "Setan Gundul Budha Myanmar Harus Diberi Pelajaran Setimpal" (Arrahmah.com, akses15 Juni 2013), ini tentu sangat terlihat provokatif dan sebagai media yang membawa simbol agama tentu hal ini akan sulit diterima dengan akal sehat. Contoh lainnya "Muslim Rohingya menderita diskriminasi dan penganiayaan yang hampir tak pernah henti" (Arrahmah.com, akses 15 Juni 2013). Dari dua contoh pemberitaan diatas dapat kita lihat bagaimana ada dua dikotomi yang berbeda yang ditampilkan oleh media Arrahman.com. Disatu sisi orang Budha Myanmar di hadirkan dengan sangat hina dengan kata-kata yang cendrung sangat melecehkan dengan kata "Gundul", sedangkan disisi lain orang muslim rohingya ditampilkan dengan kondisi sangat memprihatinkan dengan menggunakan kata "penganiyaan yang hapir tak penah henti". Tentu berita itu sangat sangat provokatif dan mengandung unsur propaganda. Padahal bila kita pelajari dalam kaidah jurnalistik, setiap wartawan harus bersikap profesional dan netral. Dimana harus ada keseimbangan fakta dalam suatu pemberitaan, namu tidak dengan apa yang terjadi di media Arrahmah.com. Keberpihakan inilah yang semakin penulis anggap relefan dengan apa yang dikatakan oleh paradigma kritis bahwa tidak ada media yang bisa netral, selalu ada kepentingan di balik pemberitaanya.

\section{Kata Kunci: Etnis Muslim Rohingya, Media Massa Islam PENDAHULUAN}

Sejak era reformasi, kebebasan pers semakin terbuka dan tak terbendung lagi kehadirannya. Hal ini dikarenakan, untuk membuat sebuah media (koran, majalah, dll) tidak diperlukan SIUP (Surat Izin Usaha Penerbitan) seperti pada masa Orde Baru. SIUP adalah barang mahal yang harus dimiliki oleh semua pihak yang mau mendirikan perusahaan pers pada masa Orde Baru (Hill, 2011, h. 53). Dari sekian banyak media yang ada sekarang, pers yang memegang ideologi Islam hanya sedikit jika dibandingkan dengan pers umum. Pers Islam dinilai tidak mampu bertahan dengan gempuran perkembangan jaman yang menuntut segala sesuatu untuk menjadi lebih bebas. Dengan ideologi Islami, pers Islam dianggap kolot karena selalu memandang isu dari sudut pandang keislaman. Akibatnya sudut pandang pers semakin mengerucut dan hanya bisa dinikmati oleh kalangan tertentu saja. 
Di lain pihak, pers Islam juga lemah dalam dukungan dana. Tidak ada investor yang mau mendanai secara sukarela pers berideologi Islami. Para calon investor selalu menggunakan pemikiran matrealistis dan berfokus pada prinsip 'laba-rugi'. Jarang yang ada berpikiran untuk 'mengorbankan harta demi syiar Islam'. Bahkan ketika citra Islam diserang dengan pencitraan negatif (fundamentalis, ekstrimis, bahkan teroris) oleh media/pers non-Islam (Romli, 2003, h. 50).

Faktor lain yang menyebabkan pers Islam semakin 'kurus' antara lain; lemahnya manajemen. Dari segi keredaksian, gaya bahasa, teknik penulisan, pemilihan dan pemilahan topik, serta penampilan produk (termasuk cover, dll) dianggap kurang atau tidak menarik minat dan perhatian orang untuk membaca. Dari segi pemasaran, tenaga pemasar tidak agresif, hanya "menunggu bola" dan "pelit", karena tidak mau berpromosi (Assegaf, 1985, h. 10). Padahal dalam manajemen modern, promosi tidak hanya digunakan sebagai alat untuk menarik minat pembeli, tapi juga berfungsi sebagai pembentuk citra positif serta membentuk fanatisme dan kebanggaan (gengsi) pembaca. Lalu yang masih terasa hingga saat ini adalah, pers Islam cenderung sektarian, kurang atau tidak independen, dan eksklusif (Romli, 2003, h. 50).

Sikap sektarian atau pengkotak-kotakan berdasarkan sekte atau aliran tentu saja tidak menguntungkan dari segi finansial. Penyebaran informasi hanya beredar dan hanya bisa dinikmati oleh kalangan tertentu. Banyak pers Islam yang muncul menyuarakan kepentingan golongannya. Sebagai contoh Majalah Risalah adalah bacaan warga Persis, Suara Muhammadiyah milik warga Muhammadiyah, juga Majalah Pesantren milik warga NU. Dengan pengkotakan-kotakan seperti ini, pers Islam tidak bisa menjangkau pembaca yang lebih luas lagi (Romli, 2003, h. 53).

Beberapa pers Islam yang terbit di Indonesia dan bertahan dengan jumlah pembaca yang banyak antara lain Situs eramuslim.com, Harian Republika dan Majalah Sabili. Bebepa pers Islam tersebut masih cukup eksis 
hingga kini. Mereka mempunyai segmentasi konsumen yang cukup loyal. Ini cukup bisa kita pahami karena Indonesia merupakan negara dengan penduduk islam terbesar di dunia.

Harian Republika adalah koran nasional yang terbit perdana pada 4 Januari 1993. Koran ini lahir oleh kalangan komunitas muslim bagi publik Indonesia. Pemaparan Arahman Ali (2007), dalam buku Tanah Air Bahasa: Seratus Jejak Pers Indonesia, Republika yang memiliki segmentasi khusus pembaca umat muslim Indonesia memang merupakan produk perwujudan dari sebuah proses perjuangan panjang umat Islam dalam membentuk surat kabar sendiri (h. 370). Kelahiran koran ini tak bisa dilepaskan dari upaya Ikatan Cendikiawan Muslim Indonesia (ICMI) yang saat itu diketuai BJ Habibie. Menurut David T. Hill (2011), Republika dibangun setelah ICMI mengidentifikasikan 'musuh bersama', yaitu kelompok minoritas yang menguasai konglomerasi media yang dengna sengaja menutupi kegiatankegiatan Islam secara profesional.

Sementara itu majalah Sabili terbit pertama kali pada tahun 1988 sebagai media bawah tanah yang tidak memiliki Surat Izin Usaha Penerbitan Pers (SIUP). Sebagai media bawah tanah, awalnya Sabili disebarkan dalam kelompok-kelompok terbatas, hanya pada kalangan Tarbiyah. Sabili memiliki visi: menjadi media pengendali informasi dan advokasi umat Islam, dan misi: menjaga akidah dan ukhuwah ummat serta mendukung syariat Islam; Menyajikan ajaran Islam yang utuh berdasarkan al-qur'an dan sunnah; Membentuk generasi muda muslim yang berwawasan kedepan; Melahirkan jurnalis da'i yang profesional, penuh dedikasi dan berakhlak mulia; Membangun citra penerbitan Islam. (Fatwa Sesat Media Ummat, http://majemuk.blogspot.com/2007/07/fatwa-sesat-media-ummat.html diakses tanggal 16 Juni 2012)

Di jalur online ada eramuslim.com. sebagai media yang bernafaskan islam juga menyoroti isu-isu dari sudut pandang Islami. Dengan tagline 
"Media Islam Rujukan", eramuslim.com mendeklarasikan dirinya sebagai media yang dapat dijadikan rujukan bagi umat, dalam hal ini pembaca. Sementara arrahmah.com mendeklarasikan dirinya sebagai media yang peduli akan isu-isu islam dunia denga tagline "Berita Dunia Islam Terdepan", (Eramuslim.com \& Arrahmah.com, Akses 13 Juni 2013).

Walaupun dengan ideologi yang cenderung bersandar pada sisi keislaman, namun tidak semua media islam tersebut meliput dan menampilkan berita-berita yang berbau agama. Harian Republika misalnya, sebagai harian nasional menampilkan segala isu yang terjadi dalam skala nasional. Baik itu berita politik, ekonomi, olahraga dan lain sebagainya. Begitu juga dengan Majalah Sabili dan eramuslim.com. Namun di antara banyak isu yang diangkat, yang menjadi perhatian utama media bersudut pandang Islam adalah berita berbau SARA.

Isu SARA adalah isu yang sangat sensitif. SARA diartikan sebagai pandangan-pandangan atau tindakan-tindakan yang didasarkan pada sentimen identitas yang menyangkut keturunan, agama, kebangsaan atau kesukuan dan golongan (Apa itu SARA?, stoprasismedansara.blogspot.com, diakses tanggal 12 Juni 2013). Setiap tindakan yang melibatkan kekerasan (baik verbal maupun nonverbal), diskriminasi dan pelecehan yang didasarkan pada identitas diri dan golongan dapat dikatakan sebagai tindakan SARA. Tidakan seperti ini, menindas dan melecehkan kemerekaan serta hak-hak dasar yang melekat pada manusia.

Pelaku SARA sendiri dapat digolongkan dalam tiga kategori, diantaranya;

1. Individual, yaitu tindakan SARA yang dilakukan oleh individu maupun kelompok. Termasuk di dalam kategori ini adalah tindakan maupun pernyataan yag bersifat menyerang, mengintimidasi, melecehkan dan menghina identitas diri maupun golongan. 
2. Institusional, yaitu tindakan SARA yang dilakukan oleh institusi, termasuk negara, baik secara langsung maupun tidak langsung, sengaja atau tidak sengaja telah membuat peraturan diskriminatif dalam struktur organisasi maupun kebijakannya.

3. Kultural, yaitu penyebaran mitos, tradisi dan ide-ide diskriminatif melalui struktur budaya masyarakat.

\section{HASIL DAN PEMBAHASAN}

\section{Media Islam di Indonesia dan Etnis Rohingya}

Salah satu kasus SARA yang banyak diberitakan akhir-akhir ini oleh media kita adalah tentang konflik etnis di Myanmar antara entis Rohingya dan etnis Bhurma. Pada Ramadhan tahun 2012, masyarakat dunia dikejutkan dengan kasus yang melibatkan unsur SARA. Kasus ini terjadi di Myanmar dan lebih dikenal dengan kasus 'Muslim Rohingya'. Kasus ini bermula pada 28 Mei 2012. Seorang gadis Buddha, Ma Thida Htwe (28) dari Desa Kyauknimaw dilaporkan tewas ditikam di hutan dekat jalan menuju Kyaukhtayan, saat pulang bekerja sebagai tukang jahit. Kasus tersebut dilaporkan sebagai kasus pemerkosaan dan pembunuhan. Hari berikutnya, polisi sudah menetapkan tersangka, yakni Rawshi bin U Kyaw Thaung, Rawphi bin Sweyuktamauk, dan Khochi bin Akwechay. Ketiganya berasal dari suku Bengali Muslim. Dari hasil penyelidikan, tersangka Rawshi dibantu Rawphi dan Kochi merampok, memperkosa, dan membunuh untuk mendapatkan perhiasan korban guna pesta pernikahan. Tidak berapa lama, kasus membali mencuat dan memanas. (makassar.tribunnews.com diakses tanggal 14 Juni 2013).

Namun menurut situs arrahmah.com, pembataian dan pemerkosaan yang dilakukan oleh etnis muslim Rohingya terhadap perempuan Budha adalah sebuah fitnah. Menurut situs arrahmah, pembantainya sebenarnya dilakukan oleh kekasih korban sendiri bersama denga teman-temannya 
(arrahmah.com, akses 14 Juni 2013). Namun terlepas dari benar tidaknya kabar itu, pertikaian antara etnis rohingya dan etnis burma sudah terjadi.

Dari situlah kasus etnis ini berawal. Dari yang awalnya kasus pembunuhan dan pemerkosaan terhadap salah satu orang yang tidak jelas siapa pelakunya, kini merembet ke soal etnis dan bahkan sudah sampai ke masalah agama. Awalnya ini hanya merupakan kasus tindak kriminal biasa. Namun karena pemberitaan yang gencar dari wartawan Myanmar, kasus ini menjadi kasus etnis yang melibatkan dunia, ditambah lagi dengan banyaknya entis rohingya yang mengusngsi dan mencari amnesti ke berbagai negara di Asia termasuk Indonesia.

Konflik etnis di Myanmar antara etnis Rohingya kaum minoritas dan etnis setempat yakni Bhurma yang mayoritas baragama Budha sudah terjadi berpuluh-puluh tahun yang lalu. Menurut Nuswanto, (Kompasnia. Com, diakses 14 Juni 2013) pembantaian etnis Rohingya pernah terjadi pada tahun 1942. Sekitar 100.000 orang Rohingya dibantai dan disempitkan ruang gerak dan tempat tinggalnya menjadi hanya di negeri Arakan bagian utara (Northern Rakhine). Penyiksaaa terus berlanjut, dan mencapai puncaknya pada tahun 1962, ketika rezim militer U Ne Win mengambil alih pemerintahan negara Burma.

Melihat dari sejarahnya, etnis Rohingya mempunyai sejarah yang panjang. Awal keberadaan etnis Rohingya pun juga menjadi perdebatan. Ada yang berpendapat bahwa sejarah orang Rohingya bertarikh dari awal kurun ke-7 di Negeri Arakan, yang menjadi penempatan pedagang-pedagang Arab yang beragama Islam. Namun data mengenai pendapat tersebut sedikit. Rohingya merupakan sebuah warna yang berbeda bagi masyarakat Myanmar sebab mayoritas etnis Rohingya beragama Islam dan hidup di tengah penduduk Myanmar yang beragama Budha. Selain itu dari segi penggunaan bahasa dan bentuk kemiripan wajah, etnis Rohingya tidak memiliki kedekatan 
dengan penduduk Myanmar pada umumnya melainkan memiliki kedekatan dengan Bangladesh, India maupun Arab (Yegar, 2002).

Sejarah lain mengatakan bahwa cikal bakal kelompok Rohingya terlacak sejak jaman Kerajaan Mrauk U, khususnya pada zaman Raja Narameikhla (1430 - 1434). Setelah dibuang ke Bengal, Narameikhla lalu menguasai kembali Mrauk U dengan bantuan Sultan Bengal. Seiring berkuasanya Narameikhla, masuk pula penduduk Muslim dari Bengal kewilayah Arakan, Rakhine. Dalam perkembangannnya, jumlah penduduk Rohingya terus meningkat, terutama saat Inggris menguasai Rakhine. Karena kurangnya populasi di Rakhine, Inggris memasukkan orang Bengali ke Rakhine untuk bekerja sebagai petani. Sampai saat ini pun, kebanyakan orang Rohingya bekerja di sektor agraris. (Suhardijanto, Mizan.com, diakses tanggal 2 Juni 213)

Sementara itu, etnis Rohingya yang mendiami wilayah Arakan, Rakhine, Myanmar bisa dikatakan etnis yang kontroversial. Di satu sisi, etnis ini merasa sudah lama mendiami wilayah ini dan sejarah membuktikannya. Namun di sisi lain, pemerintah Myanmar tidak mau mengakui kewarganegaraan etnis ini serta mengganggap etnik Rohingya imigran gelap dan pelintas batas dari Bangladesh. Akibatnya warga Rohingya tidak bisa mengakses pendidikan, layanan kesehatan dan bahkan pekerjaan yang layak. Mereka benar-benar terabaikan (Suhendi, 2010, h. 30)

Dari segi kebahasaan, bahasa yang di klaim sebagai bahasa Rohingya sebenarnya termasuk ke dalam rumpun bahasa Indo-Eropa, khususnya kerabat bahasa Indo-Arya. Lebih detail lagi, bahasa Rohingya dikategorikan sebagai bahasa-bahasa Chittagonia yang dituturkan oleh masyarakat di bagian tenggara Bangladesh. Sementara itu, kebanyakan bahasa di Myanmar tergolong rumpun Tai Kadai, Austroasiatik, atau Sino-Tibetan. Jadi, jelas bahwa kelompok etnis Rohingya merupakan keturunan etnis Bengali, 
khususnya sub etnis Chittagonia yang tinggal di Bangladesh tenggara. (rohingya.org, diakses tanggal 14 Juni 2013)

Isu mengenai kasus Rohingya kini memang mulai mereda, namun itu tidak berarti harus dilupakan. Selain karena mereka merupakan bagian dari suku yang terasingkan, tapi juga sebagai suku atau etnis yang yang beragamakan Islam. Tentu hal itu menjadi nilai lebih ketika media Islam di Indonesia meliputnya. Ditambah lagi masih banyak pengungsi rohingya yang masih berada di Indonesia. kemudian ini menjadi penting bagi pers Indonesia, terutama pers yang berideologikan Islam. Karena ada kesamaan ideologi maka tidak mengherankan ketika banyak pers Islam tersebut yang memberitakn tentang kasus etnis Rohingya.

Tidak jarang media Islam tersebut melakukan provokasi orang-orang muslim untuk melakukan jihad. Media Islam melakukan propaganda sedemikian rupa, mulai dari membawa unsur-unsur agama yang sangat sentimentil seperti kafir, surga, perintah Allah SWT, dll. Atau dengan cara penyajian teks berita serta foto yang kadang-kadang di dramatisi hingga dapat menggugah pembacanya melakukan tindakan jihad. Apalagi tawaran yang di berikan cukup menarik bila berjihad yakni surga. Contohnya berita di arrahmah.Com dengan judul "Ulama Rohingya: Jihad fi sabilillah wajib di Myanmar sekarang ini” (arrahmah.Com, diakses 14 Juni 2013). Nah kemudian pertanyaanya apakah benar hal yang disajikan media Islam tersebut adalah gambaran nyata dari apa yang terjadi di Myanmar?. Apakah memang jihad diperlukan ketika kita sebenarnya tidak benar-benar tahu apa yang terjadi disana, karena informasi yang kita dengar bersumber hanya dari satu media dan tidak didapat dengan kehadiran langsung?. Atau jangan-jangan kita hanya dimainkan emosi kita oleh media?. karena bagaimanapun pesan-pesan di media massa diyakini memiliki kekuatan yang signifikan dalam mempengaruhi prilaku manusia (Coreteu dan William, didalam Sulhan, 2006, h. 261). 
Menarik kemudian melihat bagaimana pers Islam di Indonesia merepresentasikan etnis Rohingya di dalam pemberitaanya. Bagaimana media Islam di Indonesia menghadirkan atau mengkonstruksi realitas etnis rohingya melalui teks pemberitaannya. Hal ini tentu berbeda dengan media cetak mainstrim yang banyak kita ketahui seperti Tempo, Kompas, dan lainnya yang cendrung lebih berideologi nasionalis. Untuk itu penulis akan melihat media dalam memberitakan persoalan ini dari sudut pandang paradigma kritis. Menurut pandangan paradigma kritis tidak ada media yang netral dalam memberitakan suatu persoalan. Menurut Eriyanto (2009, h. 48), paradigma kritis melihat bahwa media bukanlah suatu yang bebas dan netral. Media justru dimiliki kelompok tertentu yang digunakan untuk mendominasi kelompok yang tidak dominan.

Bertolak pada pemikiran Mc Quail, dalam buku Mass Comunmunication Theories (2000, h. 66), pertama, melihat media massa sebagai window on events and experiens. Media dipandang sebagai jendela yang memungkinkan khalayak "melihat" apa yang sedang terjadi di luar sana. Atau media sebagai sarana belajar untuk mengetahui berbagai peristiwa. Kedua, media sebagai cerminan apa yang sedang terjadi pada masyarakat dan berbagai peristiwa dunia, yang merefleksikan apa adanya. Ketiga, memandang media massa sebagai filter atau getekeeper yang menyeleksi berbagai hal untuk diberi perhatian atau tidak. Kewajiban ini mengharuskan koran, majalah, maupun media online menjadi media yang dapat menambah wawasan dan pengetahuan pembacanya terkait dengan isu-isu yang diangkat. Bukan malah membuat pemahaman pembaca terhadap isu menjadi kabur. Karena memang seperti yang kita ketahui tidak ada media yang benar-benar netral dalam mengangkat suatu persoalan.

Mungkin di level permukaan orang awam akan melihat sajian berita adalah benar adanya, namun pada level tertentu yang orang awam tidak bisa lihat seperti kebijakan redaksional, campur tangan pemilik, pemodal atau persoalan ideologi. Yang kesemuanya itu dapat menggiring arah pemberitaan 
di media massa. Jadi, menurut hemat penulis bisa jadi pemberitaan di media masih sangat tergantung pada ideologi dari pers tersebut, kepemilikan, kebijakan redaksional dan keberpihakan dari wartawan.

\section{Analisis Teks Berita: Paradigma Kritis}

Paradigma kritis lahir dari pemikir sekolah Frankfurt di Jerman atau dikenal juga sebagai Madzhab Frankfurt. Awal pemikiran ini bersumber dari gagasan Maxis tentang kelas. Yang melihat manusia sebagai suatu sistem kelas. Masyarakat dilihat sebagai suatu sistem dominasi, dam media adalah suatu sistem dominasi tersebut (Sudibyo, 2004, h. 68). Sekolah Frankfurt didirikan pada tahun 1932 Felix Weil. Maksud dari didirikannya sekolah ini adalah untuk meneliti persoalan-persoalan sosial yang terjadi di Jerman pada waktu itu. Di mana pada waktu itu Jerman dikuasai oleh Hitler. Sehinga banyak persoalan-persoaan sosial yang harus di selesaikan (Bartens, 2002, h. 194).

Tidak terkecuali media massa pada waktu itu terkena imbasnya. Hitler menjadikan media massa sebagai alat retorika dan propaganda. Media massa dijadikan pemerintah sebagai alat pengontrol publik dan menjadi sarana bagi pemerintahan Hitler untuk mengobarkan semangat para tentara. Ternyata media bukanlah suatu entitas yang netral tetapi bisa dikuasai oleh kelompok dominan. Dari sekolah inilah lahir pemikiran yang berbeda mengenai media massa, yang kemudian dikenal sebagai aliran kritis. Aliran ini percaya bahwa media adalah kelompok yang dominan untuk memanipulasi dan mengukuhkan kehadirannya sembari memarjinalkan kelompok-kelompok yang tidak dominan (Eriyanto, 2009, h. 22-23).

Masih menurut Eriyanto, Sebenarnya tandingan dari paradigma kritis adalah kaum pluralis. Paradigma pluralis ini bersumber dari pemikiran Auguste Comte, Emile Durkheim, Mark Weber, dan Ferdinan Tonnies. Pemikiran utama dari kaum pluralis adalah bahwa masyarakat merupakan wujud dari konsesus dan mengutamakan keseimbangan. Pandangan ini 
percaya dengan ide liberal yang meyakini kalau persaingan dibiarkan bebas pada akhirnya tercipta suatu keseimbangan. Selain itu kaum pluralis percaya bahwa profesionalitas, sistem kerja dan pembagian kerja dalam media massa dapat menentukan kebenarannya sendiri. maka pandangan kritis menolaknya, wartawan yang bekerja dalam suatu sisitem produksi media bukanlah otonom, bukan pula bagian dari sistem politik yang stabil, tetapi merupakan merupakan praktik ketidakseimbangan dan dominasi.

Pemikiran Madzhab Frankfurt dikembangkan lebih lanjut oleh Stuart Hall. Tidak jauh berbeda dengan pendahulunya, Hall juga mengkritik pandangan pluralis. Menurut Hall, peran konsensional dalam pandangan pluralis terjadi begitu saja dan secara alamiah, padahal menurut Hall, pembetukan konsensus ini terjadi lewat proses yang rumit, kompleks dan melibatkan kekuatan-kekuatan sosial yang ada dalam masyarakat. Hall juga berpendapat media didesain untuk memburukkan kelompok lain. Media melakukan representasi kelompok lain melalui proses yang komplek, melalui proses mendifinisikan dan penandaan, sehingga ketika ada kelompok yang buruk dalam suatu pemberitaan itu merupakan sesuatu yang wajar, terlihat alamiah (Eriyanto, 2009, h. 26).

Hall juga berargumen soal konstruksi realitas. Realitas di dalam media tidak dipandang suatu perangkat fakta, tapi dari hasil pandangan kelompok tertentu dari pembentukan realitas. Berbeda dengan pandangan pluralis yang melihat konstruksi adalah sesuat yang terjadi dengan sendirinya, dalam tradisi kritis realitas tersebut diproduksi oleh representasi dari kekuatan-kekuatan sosial dominan yang ada dalam masyarakat.

Dalam pandangan Hall (dalam Eriyanto, 2009, h. 29-31), pembentukan realitas terjadi karena dua hal. Peratama, bahasa. Bahasa berperan dalam proses pemberian makna. Kenapa terkadang kita hanya bisa menerima satu makna dalam peristiwa. Kenapa tidak bisa kita terima ketika makna yang lain diungkapkan. Menurut Hall, lagi-lagi karena ada faktor 
dominasi pemaknaan di dalam suatu entitas sosial kita. Makna timbul karena proses pertarungan sosial, di mana semua pihak selalu ingin menunjukkan kebenarannya masing-masing dan bahasa adalah tempat dimana makna di artikulasikan.

Kedua, politik penandaan. Titik perhatian Hall adalah peran media dalam menandakan suatu peristiwa atau realitas dalam pandangan tertentu. Serta menunjukkan bagaimana kekuasaan ideologi disini berperan. Ideologi menjadi bidang di mana pertarungan dari kelompok yang ada dalam masyarakat. oleh karena itu ideologi melekat dalam produksi sosial, produksi media dan sistem budaya. Efek dari ideologi dalam sistem media itu adalah menampilkan pesan dan realitas hasil konstruksi tersebut tampak seolah-olah nyata, natural, dan benar.

\section{Representasi Etnis Rohingya di Media Massa Islam: Stuart Hall Prespektif}

Melihat pemberitaan tentang etnis Rohingya beberapa waktu belakangan ini seringkali kita disuguhkan dengan gambaran atau pemberitaan oleh media kita terutama media yang bernafaskan Islam. Berbagai bentuk pemberitaan ditampilkan oleh media tersebut. Dengan kemasan yang berbeda-beda antara satu media dengan media yang lain. Tentu akan berbeda antara media yang beraliran nasionalis dan media yang berideologikan agama. Mulai dari sudut pandang berita, pembahasaan di teks, maupun foto atau gambar yang ada di media tersebut.

Menarik bila kita cermati bagaimana media yang berideologikan Islam dalam mengemas pemberitaannya. Seringkali kita melihat media Islam di Indonesia menampilkan berita tentang etnis Rohingya dengan sangat menggebu-gebu. Terkadang penulisannya cenderung provokatif dan kelihatan seperti sangat mendramatisir. Mulai dari judul berita, konten dari berita tersebut hingga foto-foto yang ditampilkan. Seperti yang menjadi kepala berita di media online arrahmah.com ketika mengemas berita dengan 
judul "Setan Gundul Budha Myanmar Harus Diberi Pelajaran Setimpal" (arrahmah.com, akses15 Juni 2013), ini tentu sangat terlihat provokatif dan sebagai media yang membawa simbol agama tentu hal ini akan sulit diterima dengan akal sehat. Contoh lainnya "Muslim Rohingya Menderita Diskriminasi dan Penganiayaan yang Hampir Tak Pernah Henti" (Arrahmah.com, akses 15 Juni 2013).

Dari dua contoh pemberitaan di atas dapat kita lihat bagaimana ada dua dikotomi yang berbeda yang ditampilkan oleh media arrahman.com. Disatu sisi orang Budha Myanmar dihadirkan dengan sangat hina dengan kata-kata yang cenderung sangat melecehkan dengan kata "Gundul", sedangkan disisi lain orang muslim Rohingya ditampilkan dengan kondisi sangat memprihatinkan dengan menggunakan kata "penganiyaan yang hampir tak penah henti". Tentu berita itu sangat sangat provokatif dan mengandung unsur propaganda. Padahal bila kita pelajari dalam kaidah jurnalistik, setiap wartawan harus bersikap profesional dan netral. Di mana harus ada keseimbangan fakta dalam suatu pemberitaan, namu tidak dengan apa yang terjadi di media arrahmah.com. Keberpihakan inilah yang semakin penulis anggap relefan dengan apa yang dikatakan oleh paradigma kritis bahwa tidak ada media yang bisa netral, selalu ada kepentingan di balik pemberitaanya.

Selain itu dapat kita lihat bagaimana media Islam tersebut merepresentasikan etnis muslim Rohingya dalam teks pemberitaan. Disitu jelas terlihat bahwa media arrahmah.com menghadirkan etnis Rohingya sebagai kaum minoritas yang tertindas, terzolimi hak-haknya sebagai manusia. Bahkan terkadang seringkali media Islam menganjurkan untuk melakukan perbuatan jihad atau berperang malawan musuh. Tentu di sini jihad diartikan sebagai berperang. Yang menjadi pertanyaan adalah apakah benar demikian yang terjadi di Myanmar? Atau jangan-jangan yang terjadi pada etnis Rohingya tidak seperti apa yang diberitakan oleh media-media Islam di 
Indonesia. Karena menurut Hall (1997), Suatu peritiwa seringkali dikonstruksi oleh media melalui bahasa. Serta bahasa yang kemudian menghasilkan makna digunakan tregantung apa yang dikehendaki atau ditulis (dalam kontek penulisan berita) oleh individu yang memproduksi makna tersebut.

Menurut Stuart Hall (1997, h. 25), dalam pengertian representasi melalui Theory of Representation. Terdapat tiga pendekatan untuk menjelaskan bagaimana representasi dari bahasa menghasilkan sebuah makna. Ketiga pendekatan tersebut adalah the reflective, the intentional dan the constructionis (contructionist approach). Di dalam the reflective approach, makna ditujukan untuk mengelabui objek yang dimaksudkan, baik itu orang, ide ataupun suatu kejadian di dunia yang nyata, dan fungsi bahasa sebagai cermin, untuk merefleksikan maksud sebenarnya seperti keadaan yang sebenarnya di dunia. Sedangkan intentional approach merupakan pendekatan yang berkaitan erat dengan pembicara atau penulis yang menekankan pada diri sendiri mengenai pemaknaan yang unik di dunia ini melalui bahasa. Kata-kata yang dihasilkan memiliki makna sesuai dengan apa yang diinginkan oleh penulis.

Penulisan berita tersebut kemudian tidak lepas dari ideologi yang dianut suatu media. Karena menurut pandangan paradigma kritis, tidak ada wartawan atau jurnalis yang otonom. Mereka selalu berada di dalam dominasi sistem dan kekuasaan. Jadi penulisan yang dilakukan oleh jurnalis tentang Islam Rohingya bukanlah suatu yang berdiri sendiri, bukan suatu yang tunggal. Ada ideologi tertentu yang melatarbelakangi penulisan suatu berita. Karena menurut Hall (dalam Eriyanto, 2009, h. 29-31), ideologi melekat dalam produksi sosial, produksi media dan sistem budaya. Efek dari ideologi dalam sistem media itu adalah menampilkan pesan dan realitas hasil konstruksi tesebut tampak seolah-olah nyata, natural, dan benar.

Selain itu Hall menurunkan 3 intepretasi yang digunakan individu untuk menafsirkan atau memberi respons terhadap persepsi mengenai 
kondisi dalam masyarakat, yaitu: dominan/hegemonic code, audiens yang menyetujui dan menerima langsung apa saja yang disajikan oleh media, menerima penuh ideology yang dari program tayangan tanpa ada penolakan atau ketidaksetujuan terhadapnya. Negotiated code, penonton mencampurkan intepretasinya dengan pengalaman-pengalaman sosial tertentu mereka. Penonton yang masuk kategori negosiasi ini bertindak antara adaptif dan oposisi terhadap intepretasi pesan atau ideology dalam media. Oppositional code, audiens melawan atau berlawanan dengan representasi yang ditawarkan dalam tayangan dengan cara yang berbeda dengan pembacaan yang telah ditawarkan (Hall, 1997, h. 138).

Dalam konteks interpretasi Hall, interpretasi yang dilakukan oleh audiens media Islam ketika menanggapi isu berita tersebut tentu sangat beragam. Mulai dari audien yang menerima begitu saja apa yang diberitakan atau sebaliknya audiens akan bersifat kritis atas isi media. Mengingat Indonesia adalah negara muslim terbesar di dunia. Apalagi hal yang diberitakan adalah isu yang sangat sentimentil bagi masyarakat Indonesia yakni agama. Gambaran yang direpresentasikan oleh media Islam atas suku Rohingya akan sangat mempengaruhi dukungan atas etnis Rohingya. Realitas yang dibangun oleh media Islam dengan sedemikian rupa dapat mempengaruhi pembaca. Terutama bagi audiens yang hanya mendapat informasi dari pemberitaan dari media Islam saja. Karena tidak terjadi pemasukan informasi yang seimbang. Beda halnya kemudian bila audiens tersebut mencari informasi dari berbagai macam media.

Jadi konstruksi realitas yang dibangun oleh media dalam konteks tulisan ini media Islam adalah tidak lepas dari ideologi yang menjadi dasar dari media tersebut. Islam sebagai dasar ideologi kemudian dijadikan sebagai landasan untuk mempengaruhi audiens mereka untuk mendukung etnis Rohingya. Etnis Rohingya yang terzalimi, tertidas, terpinggirkan, atau terusir adalah konstruk yang sering digambarkan dalam media Islam di Indonesia. 
Itu berdampak pada perilaku audiens yang memberikan dukungan atas etnis Rohingya. Apa lagi adanya doktrin agama berupa janji-janji surga semakin memperkuat audien bagi pembaca media Islam tersebut.

Tidak ada media yang benar-benar bisa netral dalam memberitakan suatu suatu isu. Faktor seperti pemilik media, ideologi, pemodal, iklan, dan regulasi pemerintah lebih menentukan isi media (Sudibyo, 2004, h. 71). Dalam konteks ini tidak ada profesionalitas kerja wartawan dalam suatu media seperti pemikiran kaum pluralis. Kemudian menjadi wajar apabila media yang bernafaskan Islam selalu membela kepentingan kaum muslim. Betapapun salahnya orang muslim, akan tetap diberitakan dengan pembelaan. Karena posisi mereka adalah sebagai media yang membela kaum Islam. Namun perlu diingat Islam disini adalah Islam versi media tersebut.

\section{PENUTUP}

Berdasarkan pembahasan di atas, dari ditarik sebuah kesimpulan, bahwa penyajian berita pada media massa dipengaruhi oleh berbagai factor seperti; ideologi, pemodal, dan sebagainya. Dalam hal pemberitaan konflik yang terjadi di Myanmar media Islam (arrahmah.com) merepresentasikan etnis muslim Rohingya sebagai kaum minoritas yang tertindas, terzolimi hakhaknya sebagai manusia. Bahkan terkadang seringkali media Islam menganjurkan untuk melakukan perbuatan jihad atau berperang malawan musuh. Tentu di sini jihad diartikan sebagai berperang. Yang menjadi pertanyaan adalah apakah benar demikian yang terjadi di Myanmar? Atau jangan-jangan yang terjadi pada etnis Rohingya tidak seperti apa yang diberitakan oleh media-media Islam di Indonesia. Karena menurut Hall (1997), Suatu peritiwa seringkali dikonstruksi oleh media melalui bahasa.

Serta bahasa yang kemudian menghasilkan makna digunakan tregantung apa yang dikehendaki atau ditulis (dalam kontek penulisan berita) oleh individu yang memproduksi makna tersebut. 


\section{DAFTAR REFERENSI}

Ali, Arahman, et, al. (2007). Tanah Air Bahasa: Seratus Jejak Pers Indonesia. Jakarta: I:Boekoe.

ARNO. (2008). Learn About Robingya.

http://www.rohingya.org/portal/index.php/learn-about-rohingya.pdf. diakses tanggal 14 Juni 2013.

Assegaf, Dja'far H. (1985). Jurnalistik Masa kini: pengantar ke Praktik kewartawanan. Jakarta: Ghalia Indonesia.

Eriyanto. (2009). Analisis Wacana: Pengantar Analisis Teks Media. Yogyakarta: LKIS.

Fatwa Sesat Media Ummat, http://majemuk.blogspot.com/2007/07/fatwasesat-media-ummat.html. diakses tanggal 16 Juni 2012.

Hall, Stuart. (1997). Representation : Cultural Representation and Signifying Practises. London: Sage.

Hill, David. T. (2011). Pers Di Masa Orde Baru. Jakarta: Obor Pustaka Indonesia.

K. Bertens. (2002). Fisafat Barat Kontemporer: Inggris-Jerman. Jakarta: Gramedia.

Musa, Samir. (2013). Setan Gundul Budha Myanmar Harus Diberi Pelajaran Setimpal. http://www.arrahmah.com/news/2013/04/22/setan-gundulbudha-myanmar-harus-diberi-pelajaran-setimpal.html. diakses tanggal 14 Juni 2013.

McQuail, Denis. (2000). Mass Communication Theories. Fourth edition. London: Sage Publications.

Muttaqin, A.Z. (2013). Ulama Rohingya Jihad fi Sabilillah Wajib di Myanmar Sekarang Ini. http://www.arrahmah.com/news/2013/06/20/ulamarohingya-jihad-fi-sabilillah-wajib-di-myanmar-sekarang-ini.html. diakses tanggal 14 Juni 2013.

Nuswanto, Heru Susetyo. (2012). Rohingnya 101: Sejarah Masalab Kekerasan dan Tuntutan. http://politik.kompasiana.com/2012/08/23/rohingya-101sejarah-masalah-kekerasan-dan-tuntutan-488287.html

Prajarto, Nunung. Edt. (2004). Komunikasi, Negara, dan Masyarakat. Yogyakarta: Fisipol UGM.

Romli, Asep Syamsul E. (2003). Jurnalistik Dakwah. Bandung: Remaja Rosda Karya.

Siraaj. (2012). Sekelumit Fakta tentang Genosida Rohingya di Burma. http://www.arrahmah.com/read/2012/08/03/22150-sekelumit fakta- 
tentang-genosida-muslim-rohingya-di-burma.html. diakses tanggal 14 Juni 2013.

Suhaedi, Ahmad. (2010). Islam, identitas, dan Minoritas di Asia Tenggara. Jakarta: LIPI.

Suharjianto, Totok. (2012). Mengenal Etnis Robingya dari Sudut Panjang Sejarah, http://mizan.com/news_det/mengenal-etnis-rohingya-dari-sudutpandang-sejarah.html. diakses tanggal 14 Juni 2013.

Sulhan, Muhamad. (2006). Dayak yang Menang, Indonesia yang Malang: Representasi Identitas Etnik. Dayak di Media Massa. Yogyakarta: Sang Surya Grafika.

Sumardi, Edi. Inilah Pemantik Awal Tragedi Robingya, http://makassar.tribunnews.com/2012/08/07/inilah-pemantik-awaltragedi-rohingya. diakses tanggal 14 Juni 2013

Siraaj. (2013). Muslim Robingnya Muslim yang Terlupakan.

http://www.arrahmah.com/video/muslim-rohingya-orang-orangyang-terlupakan.html. diakses tanggal 14 Juni 2013.

Yegar, Moshe. (2002). The Muslim of Burma: A Minority Group (Southeast Asia Area Stuides). Wiesbeden: Otto Harassowitz. 